\title{
Analysis of Genetic Variability to Improve Yield and Resistance to Bacterial Leaf Blight in Rice (Oryza sativa L) Germplasm
}

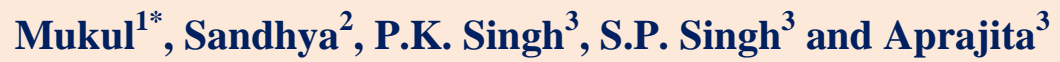 \\ ${ }^{1}$ Department of Genetics and Plant Breeding, Institute of Agricultural \\ Sciences, Banaras Hindu University, Varanasi-221005, India \\ ${ }^{2}$ Department of GPB, AU, Kota, Rajasthan, India \\ ${ }^{3}$ Department of GPB, IAS, BHU, Varanasi, India
}

*Corresponding author

\section{Keywords \\ Correlation, Genetic advance, Grain yield, Heritability, GCV, PCV \\ Article Info \\ Accepted: \\ 04 March 2019 \\ Available Online: \\ 10 April 2019}

\section{A B S T R A C T}

One hundred indigenous collection of rice germplasm were evaluated for ten quantitative traits to assess the genetic variability, heritability, associations and estimation of yield related traits including area under disease progress curve for bacterial leaf blight. was present for all the traits,. In all germplasm, the analysis of variance revealed a wide range of variability and significant differences for the characters under study, indicating the presence of high genetic variability among the genotypes and considerable scope for selection. The estimates of genotypic coefficient of variance were lower than the respective phenotypic coefficient of variance, indicating the influence of environmental factors on the expression of the traits studied. The high heritability was observed for grain yield per plant, thousand grain weight, total spikelets per panicle, number of effective tillers per plant, plant height, grain weight per panicle, days to maturity and days to 50 per cent flowering. The phenotypic correlation coefficients were positive and highly significant between grain yield per plant with days to $50 \%$ flowering, days to maturity, total spikelets per panicle, grain weight per panicle and thousand grain weight. The correlation between area under disease progress curve and number of effective tillers per plant and thousand grain weight was positive.

\section{Introduction}

Rice (Oryza sativa L.) is one of the oldest domesticated cereal crops which provides food for more than half of the world's population and constitutes a major source of calories for urban and rural inhabitants (Khush, 2005). Xanthomonas oryzae pv. oryzae (Xoo) is the causal organism of Bacterial leaf blight disease, one of the most devastating diseases affecting entire rice acreage. It causes severe yield losses of up to $80 \%$, depending on the different stage of the crop, cultivar susceptibility and the environmental conditions (Srinivasan and Gnanamanickam, 2005).

Crop improvement for grain yield has been achieved in rice through effective use of germplasm and fixing desirable traits 
combinations. However, there are still possibilities to increase the yield output through proper breeding technologies along with molecular studies. Grain yield is a complex quantitative trait and is the result of interaction of many variables. The existence of correlation between traits may be attributed to the presence of linkage or pleiotropic effect of genes or physiological and development relationship or environmental effect or in combination of all (Oad et al., 2002). The importance of correlation analysis is particularly appreciable when highly heritable characters associated with a complex trait like yield and particular a disease resistance are identified, and successfully used as criteria for effective selection to achieve high yield. To accumulate yield contributing characters together with bacterial blight resistance, it is essential to know the association among various traits. Therefore, the present investigation was undertaken to study the variability, heritability and estimation of associations for yield related traits in indigenously collected rice germplasm and possible breeding strategies to improve yield with enhanced resistance are discussed.

\section{Materials and Methods}

The hundred rice germplasm including two checks PB-1and IRBB-55 were raised in a RBD during Kharif-2014-15 at Agricultural Research Farm, Institute of Agricultural Sciences, Banaras Hindu University, Varanasi, India.

The culture of Xanthomonas oryzae pv. oryzae (strain BX043 wild type) was obtained from and sub-cultured on peptone sucrose agar (PSA) medium (Distilled water:1L, Sucrose: 20g, Peptone: 5g, $\mathrm{K}_{2} \mathrm{HPO}_{4}$ : 0.5g, $\mathrm{MgSO}_{4} .7 \mathrm{H}_{2} \mathrm{O}: 0.25 \mathrm{~g}$ and Agar: $15 \mathrm{~g}$ ) and maintained it at $\mathrm{pH} 7.2-7.4$. These germplasm were grown in replications and spacing was maintained at $20 \mathrm{~cm}$ between rows and $15 \mathrm{~cm}$ between plants. The recommended packages of practices were followed to raise healthy crops.

The culture of Xanthomonas oryzae pv. oryzae (strain BX043 wild type) was obtained from Department of Mycology and Plant Pathology IAS, BHU and subcultured on peptone sucrose agar medium and maintained it at pH $7.2-7.4$ (Fahy and Persley, 1983) and pathogenicity test, clipping method was used to inoculation the rice plants with Xanthomonas oryzae pv. oryzae. After inoculation, the plants were observed after every $24 \mathrm{hrs}$ time intervals to note the appearance of disease symptoms, and lesion length were recorded at $8,16,24$ and 32 days after inoculation (DAI).

After eliminating the border plants, observations were recorded on ten randomly selected plants from rice germplasm including two checks from each replication on days to $50 \%$ flowering (DF), days to maturity (DM), plant height $(\mathrm{PH})$, panicle length (PL), Grain weight per panicle (GWP), number of effective tillers per plant (ET), total number of spikelet per panicle (TSP), thousand grain weight (TGW), grain yield per plant (GYP) and area under disease progress curve (AUDPC), and mean value were used for statistical analysis.

\section{Statistical analysis}

The data were analyzed for variability (ANOVA) as per procedure given by Panse and Sukhatme (1985) (Table 1). Differences were declared statistically significant at $\mathrm{P}<$ 0.05 . In this study, phenotypic coefficient of variation $(\mathrm{PCV})$ and genotypic coefficient of variation $(\mathrm{GCV})$ were calculated by the formula given by Burton and Devane (1953). Heritability in broad sense $\left(\mathrm{h}^{2}\right)$ and genetic advance as percent of mean were estimated by the formula as suggested by Allard (1960) and 
correlation coefficients among traits values were estimated using formula given by $\mathrm{Al}$ Jibouri et al., (1958). The area under disease progress curve (AUDPC) was calculated from disease intensity was calculated with the help of formula given by Campbell and Madden, 1990).

\section{Results and Discussion}

All the traits showed wide range of variation in all germplasm indicating ample scope for selection (Table 2). The magnitude of phenotypic coefficient of variance was higher than

corresponding genotypic coefficient of varian ces for area under disease progress curve (35.43), grain yield per plant (23.67), total number of spikelet per panicle (23.17), days to $50 \%$ flowering (17.73), thousand grain weight (17.27), number of effective tillers per plant (17.12), plant height (15.95) and days to maturity (14.32). Results of present study support the earlier observations (Ponnaiah et al., 2018, Govintharaj et al., 2016 Chouhan et al., 2014, Singh et al., 2014a), though their studies were limited to pure lines.

The high heritability was observed for grain yield per plant $(98.08 \%)$, thousand grain weight $(97.76 \%)$, total spikelets per panicle $(97.61 \%)$, number of effective tillers per plant (97.54\%), plant height $(96.79 \%)$, grain weight per panicle (92.88\%), days to maturity $(91.50 \%)$ and days to 50 per cent flowering $(90.99 \%)$. High heritability does not always indicate high genetic gain.

The heritability coupled with high genetic advance as per cent of mean under the control of additive gene action would be effective for selecting superior lines. High heritability coupled with high genetic advance as per cent of mean were recorded for total spikelets per panicle (46.58), grain yield per plant (46.49), thousand grain weight (34.77), effective tillers per plant (34.39), days to $50 \%$ flowering (33.23) and days to maturity (26.99), while high heritability coupled with low genetic advance as per cent mean were observed in panicle length (11.95) indicating that the environment is influenced by phenotypic expression. Hence, direct selection for these traits will be less effective. This finding was supported by (Ponnaiah et al., 2016 \& 2018). Variability of these traits could be predominantly due to additive gene effects, so the phenotypic selection would be effective. Days to maturity exhibited high heritably with moderate genetic advance, which is desirable. Similarly, high heritability and genetic advance as per cent of mean was earlier reported by Singh et al., (2013) in number of effective tillers per plant, grain yield per plant and Govintharaj et al., 2018; Ameenal et al., 2016 reported similar finding for plant height.

The phenotypic correlation coefficients were positive and highly significant between grain yield per plant with total spikelets per panicle $(0.249 * * *)$, grain weight per panicle $(0.227 * * *)$, thousand grain weight $(0.101 * *)$, days to maturity $\left(0.085^{*}\right)$ and days to $50 \%$ flowering $\left(0.078^{*}\right)$ (Table 3$)$. The association studied indicated that the grain yield of rice can be improved by selecting lines having higher performance for these traits. Similar trend was observed in the earlier findings (Singh et al., 2014b) for plant height, panicle length, fertile spikelet per panicle, total grains per panicle, spikelet fertility percentage and test weight, although their studies were based on pure lines.

The association of grain yield per plant with plant height (0.052), panicle length (0.035) and effective tillers per plant (0.018) was positive and very low though non-significant. Plant height was shown the positive and significant correlation with panicle length (Govintharaj et al., 2018) 
Table.1 Analysis of variance (ANOVA) for eleven quantitative traits in hundred rice germplasms

\begin{tabular}{|c|c|c|c|c|c|c|c|c|c|c|}
\hline $\begin{array}{l}\text { Source of } \\
\text { variation }\end{array}$ & $\begin{array}{c}\text { Days to } \\
50 \% \\
\text { flowering }\end{array}$ & $\begin{array}{l}\text { Days to } \\
\text { Maturity }\end{array}$ & $\begin{array}{l}\text { Plant } \\
\text { Height } \\
\text { (cm) }\end{array}$ & $\begin{array}{c}\text { Effective } \\
\text { Tillers / } \\
\text { plant }\end{array}$ & $\begin{array}{c}\text { Panicle } \\
\text { Length } \\
\text { (cm) }\end{array}$ & $\begin{array}{c}\text { Total } \\
\text { Spikelets/ } \\
\text { Panicle }\end{array}$ & $\begin{array}{l}\text { Grain } \\
\text { Weight/ } \\
\text { Panicle }\end{array}$ & $\begin{array}{l}1000 \\
\text { Grain } \\
\text { Weight } \\
\text { (g) }\end{array}$ & $\begin{array}{c}\text { Grain } \\
\text { Yield/ } \\
\text { Plant (g) }\end{array}$ & AUDPC \\
\hline Replication & 0.32 & 0.01 & 0.41 & 0.002 & 0.137 & 0.002 & 0.008 & 0.283 & 0.44 & 71406.2 \\
\hline Treatment & $3202.43 * * *$ & $3303.56 * * *$ & $3311.32 * * *$ & $13.06 * * *$ & $25.07 * * *$ & $3507.49 * * *$ & $3.467 * * *$ & $119.80 * * *$ & $118.49 * * *$ & $198244.44 * * *$ \\
\hline Error & 39.15 & 37.90 & 13.66 & 0.04 & 1.38 & 10.69 & 0.032 & 0.34 & 0.28 & 27187.78 \\
\hline
\end{tabular}

Table.2 Genetic Parameter of Ten Traits in selected rice germplasm

\begin{tabular}{|c|c|c|c|c|c|c|c|c|c|c|c|}
\hline \multicolumn{2}{|l|}{ Parameters } & \multirow{2}{*}{$\begin{array}{c}\begin{array}{c}\text { Days to } \\
\mathbf{5 0 \%} \\
\text { flowering }\end{array} \\
57.00\end{array}$} & \multirow{2}{*}{$\begin{array}{c}\text { Days to } \\
\text { Maturity } \\
86.75\end{array}$} & \multirow{2}{*}{$\begin{array}{c}\begin{array}{c}\text { Plant } \\
\text { Height } \\
(\mathbf{c m})\end{array} \\
69.43\end{array}$} & \multirow{2}{*}{$\begin{array}{c}\text { Effective } \\
\text { Tillers / } \\
\text { plant } \\
4.00\end{array}$} & \multirow{2}{*}{$\begin{array}{c}\begin{array}{c}\text { Panicle } \\
\text { Length } \\
\text { (cm) }\end{array} \\
19.28\end{array}$} & \multirow{2}{*}{\begin{tabular}{|c} 
Total \\
Spikelets/ \\
Panicle
\end{tabular}} & \multirow{2}{*}{$\begin{array}{c}\text { Grain } \\
\text { Weight/ } \\
\text { Panicle }\end{array}$} & \multirow{2}{*}{$\begin{array}{l}\mathbf{1 0 0 0} \\
\text { Grain } \\
\text { Weight } \\
\text { (g) } \\
12.42\end{array}$} & \multirow{2}{*}{$\begin{array}{c}\text { Grain } \\
\text { Yield/ } \\
\text { Plant } \\
(\text { g) } \\
8.34\end{array}$} & \multirow{2}{*}{$\begin{array}{c}\text { AUDPC } \\
190.77\end{array}$} \\
\hline Range & Min & & & & & & & & & & \\
\hline & Max & 146.50 & 172.12 & 174.65 & 11.00 & 28.67 & 182.12 & 4.12 & 32.19 & 29.75 & 1095.26 \\
\hline \multicolumn{2}{|l|}{ Mean } & 117.58 & 147.49 & 129.37 & 7.54 & 24.51 & 91.34 & 2.87 & 22.63 & 16.86 & 622.11 \\
\hline \multicolumn{2}{|l|}{$\operatorname{SEm}( \pm)$} & 2.20 & 2.16 & 1.30 & 0.07 & 0.41 & 1.15 & 0.06 & 0.20 & 0.18 & 58.00 \\
\hline \multirow[t]{2}{*}{ Variability } & PCV & 17.73 & 14.32 & 15.95 & 17.12 & 8.50 & 23.17 & 23.67 & 17.27 & 23.01 & 35.43 \\
\hline & GCV & 16.91 & 13.70 & 15.69 & 16.90 & 7.02 & 22.89 & 22.81 & 17.07 & 22.79 & 23.50 \\
\hline \multicolumn{2}{|c|}{ Heritibility (\%) } & 90.99 & 91.50 & 96.79 & 97.54 & 68.21 & 97.61 & 92.88 & 97.76 & 98.08 & 44.02 \\
\hline \multicolumn{2}{|c|}{ GA as \% of mean } & 33.23 & 26.99 & 31.81 & 34.39 & 11.95 & 46.58 & 45.28 & 34.77 & 46.49 & 32.13 \\
\hline
\end{tabular}


Table.3 Correlation coefficient (phenotype) of different traits pair in rice germplasm

\begin{tabular}{|c|c|c|c|c|c|c|c|c|c|}
\hline Character & DF & DM & PH & ETP & PL & TSP & GWP & TGW & GYP \\
\hline DM & $0.977 * * *$ & & & & & & & & \\
\hline PH & $0.506 * * *$ & $0.524 * * *$ & & & & & & & \\
\hline ETP & $0.079 *$ & $0.089 *$ & $0.204 * * *$ & & & & & & \\
\hline PL & -0.055 & -0.039 & $0.169 * * *$ & $0.082 *$ & & & & & \\
\hline TSP & -0.001 & -0.003 & $-0.120 * * *$ & 0.042 & -0.019 & & & & \\
\hline GWP & -0.064 & -0.054 & 0.035 & $-0.126 * * *$ & -0.057 & 0.015 & & & \\
\hline TGW & $-0.221 * * *$ & $-0.214 * * *$ & -0.031 & $-0.168 * * *$ & $-0.098 * *$ & -0.055 & $0.648 * * *$ & & \\
\hline GYP & $0.078 *$ & $0.085^{*}$ & 0.052 & 0.018 & 0.035 & $0.249 * * *$ & $0.227 * * *$ & $0.101 * *$ & \\
\hline AUDPC & -0.017 & -0.022 & $0.074 *$ & 0.021 & 0.064 & $-0.146 * * *$ & $-0.086^{*}$ & 0.064 & $-0.455 * * *$ \\
\hline \multicolumn{10}{|c|}{$\begin{array}{l}\text { Days to maturity (DM), plant height (PH), panicle length (PL), panicle weight (PW), number of effective tillers per plant (ETP), total spikelets per } \\
\text { panicle (TSP), thousand grain weight (TGW), grain yield per plant (GYP), Area under disease progress curve (AUDPC) } \\
\text { *Significant at } p<0.05 ; *{ }^{*} \text { Significant at } p<0.01 ; * * \text { Significant at } p<0.001\end{array}$} \\
\hline
\end{tabular}

Table.4 Scale for bacterial leaf blight disease resistance

\begin{tabular}{|c|c|c|c|}
\hline Host response & Score & $\begin{array}{l}\text { No. of } \\
\text { Germplasm }\end{array}$ & Name of Germplasm \\
\hline Resistant (R) & 1 & 3 & IC 256514, IC 278776, IRBB-55 \\
\hline $\begin{array}{l}\text { Moderately } \\
\text { Resistant (MR) }\end{array}$ & 3 & 45 & 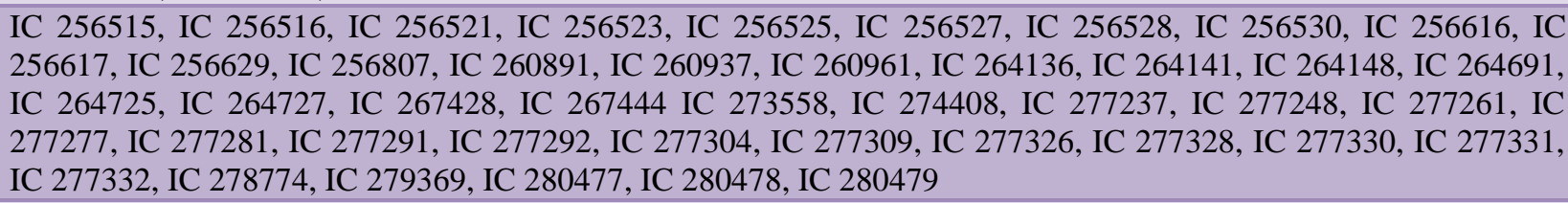 \\
\hline $\begin{array}{l}\text { Moderately } \\
\text { Susceptible (MS) }\end{array}$ & 5 & 40 & $\begin{array}{l}\text { IC 256520, IC 256534, IC 256535, IC 256537, IC 256538IC 256589, IC 256613, IC 256621, IC 256754, IC 260924, } \\
\text { IC 260964, IC 264143, IC 264149, IC 264151, IC 264229, IC 267416, IC 274397, IC 275937, IC 277193, IC } \\
277252 \text {, IC 277253, IC 277256, IC 277259, IC 277264, IC 277265, IC 277267, IC 277274, IC 277275, IC 277284, } \\
\text { IC 277287, IC 277289, IC 277290, IC 277313, IC 277314, IC 277316, IC 277317, IC 277321, IC 280466, IC } \\
280484, \text { IC } 280500\end{array}$ \\
\hline Susceptible (S) & 7 & 8 & IC 274377, IC 277319, IC 277338, IC 279355, IC 279361, IC 280502, PB-1 \\
\hline $\begin{array}{l}\text { Highly Susceptible } \\
\text { (HS) }\end{array}$ & 9 & 4 & IC 256518,IC 260917, IC 277266, IC 278777 \\
\hline
\end{tabular}


The correlation between area under disease progress curve and plant height $(0.074 *)$ was positive significant and correlation between area under disease progress curve and number of effective tillers per plant (0.021), Panicle length and thousand grain weight (0.064) was positive non-significant. The association between area under disease progress curve and total spikelets per panicle, grain weight per panicle and grain yield per panicle was negative and significant. Most of the above results of present investigation are in conformity with the finding of Govintharaj et al., (2018), Karthika et al., (2017), Singh et al., (2014), Zahid et al., (2006), Akhtar et al., (2011) and Loan et al., (2004). On the basis of disease score (1-9), germplasm classified into five categories out of which three germplasm have resistant, forty five have moderately resistance, forty have moderately susceptible, eight have susceptible and four reported highly susceptible response to the bacterial leaf blight (Table 4).

The present study, we conclude that the germplasms exhibited a wide range of variability for yield related traits and bacterial leaf blight resistance. This indicated that there is ample scope for selection of promising germplasms from present set of germplasms for yield improvement. On the basis of per se performance, genotypes viz, IC 256514 and IC 278776 were found to be the best for yield and yield contributing traits. These two germplasm, showing relatively low area under disease progress curve but had high grain yield per plant, could be further purified, multiplied and tested in different station trials, may be used as donor parent to improve the bacterial leaf blight resistance and grain yield levels in existing rice cultivars. Further, high heritability for plant height, panicle length, panicle weight, number of effective tillers and grain yield per plant coupled with high genetic advance in segregating populations enhances possibility of selecting plants with superior grain yield and resistance, if selection is practiced for grain yield and resistance simultaneously.

\section{Acknowledgements}

Authors are thankfully acknowledged the NBPGR, New Delhi and Department of Genetics and Plant Breeding, IAS, BHU, Varanasi, for providing the requisite germplasm to get this work accomplished.

\section{References}

Allard, R.W. 1960. Principles of Plant Breeding. John Wiley and Sons Inc. London, 83-108.

Ai-Jibouri, H.A., Miller, P.A. and Robinson, H.F. $\quad 1958$. Genotypic and environmental variances and covariance in an upland cotton cross of interspecific origin. Agron. J. 50: 632-636.

Akhtar, N., Nazir, M.F., Rabnawaz, A., Mahmood, T., Safdar, M. E., Asif, M., Rehman A. 2011: Estimation of heritability, correlation and path coefficient analysis in fine grain rice (Oryza sativa L.). Journal of Animal Plant Sciences, 21 (4): 660-664.

Ameenal, M. 2016. Assessment of parental genetic variability in rice. International Journal of Agricultural Science, 8(54):2917-2919.

Burton, G.W. and Devan, E.H. 1953. Estimating heritability in tall fescue (Festuca arundinaceae) from replicated clonal material. Agron. J., 45: 478-481.

Campbell, C.L. and L.V. Madden. 1990. Introduction to Plant Disease Epidemiology. John Wiley and Sons. New York.

Govintharaj, P. Manonmani, S. and Robin, S. 2016. Genetic parameters studies on bacterial blight resistance genes 
introgressed segregating population in Rice. World Scientific News, 59:8596.

Govintharaj, P., Manonmani, S. and Robin, S. 2018, Variability and genetic diversity study in an advanced segregating population of rice with bacterial blight resistance genes introgressed, Ciência e Agrotecnologia, 42(3): 291-296.

Karthika, G., Rajeswari, S., Robin, S., Govintharaj, P., Vishnu, N., Varthini, P. and Balaji A. 2017. Assessment of genetic variability, correlation and path coefficient analysis for morphological and quality traits in rice (Oryza sativa L.). Agric. Sci. Digest, 37(4): 251-256.

Khush, G.S. 2005. What it will take to feed 5 billion rice consumers in 2030. Plant Mol. Biol. 59: 1-6.

Loan, L.C., Du, P.V. and Li, Z. 2004. Molecular dissection of quantitative resistance of sheath blight in rice (Oryza sativa L.). Omonrice 12: 1-12.

Oad, F.C., Samo, M.A., Hassan, Z.U., Pompe, S.C. and Oad, N.L. 2002. Correlation and path analysis of quantitative characters of rice ratoon cultivars and advance lines. Intl. J. Agric. Biol. 4(2): 204-207.

Panse, V.G. and Sukhatme, P.V. 1985. Statical methods for Agricultural workers. 4: ICAR, New Delhi. p.
347.

Ponnaiah, G. S. T., Manonmani, S. and Robin, S. 2016. Estimates of genetic variability, heritability and genetic advance for blast resistance gene introgressed segregating population in rice. International Journal of Current Microbiology and Applied Science, 5(12):672-677.

Singh, A., Singh, A.K., Parveen, S. and Singh, P.K. 2014a. Collection, agromorphological characterization and assessment of variability in upland rice. Elect. J. Plant Breed. 5(3): 504510.

Singh, A.K., Nandan, R. and Singh, P.K. 2014b. Genetic variability and association analysis in rice germplasm under rainfed conditions. Crop Res. 47(1, 2 \& 3): 7-11.

Srinivasan, B. and Gnanamanickam, S. 2005. Identification of a new source of resistance in wild rice, Oryza rufipogon to bacterial leaf blight of rice caused by Indian strains of Xanthomonas oryzae pv. oryzae. Curr. Sci. 88: 1229-1231.

Zahid, M.A., Akhtar, M. Sabir, M. Manzoor, Z. and Awan, T.H. 2006. Correlation and path analysis studies of yield and economic traits in Basmati rice (Oryza sativa L.). Asian Journal of Plant Science, 5(4): 643-645.

\section{How to cite this article:}

Mukul, Sandhya, P.K. Singh, S.P. Singh and Aprajita. 2019. Analysis of Genetic Variability to Improve Yield and Resistance to Bacterial Leaf Blight in Rice (Oryza sativa L) Germplasm. Int.J.Curr.Microbiol.App.Sci. 8(04): 52-58. doi: https://doi.org/10.20546/ijcmas.2019.804.006 